\title{
Entrepreneurship and Crisis in Greece From a neo-Schumpeterian Perspective: A Suggestion to Stimulate the Development Process at the Local Level
}

\author{
Charis Vlados $^{1,2}$, Epaminondas Koronis ${ }^{3} \&$ Dimos Chatzinikolaou $^{1}$ \\ ${ }^{1}$ Department of Economics, Democritus University of Thrace, Komotini, Greece \\ ${ }^{2}$ School of Business, University of Nicosia, Nicosia, Cyprus \\ ${ }^{3}$ University of Westminster, London, UK \\ Correspondence: Charis Vlados, Department of Economics, Democritus University of Thrace, Komotini, 69100, \\ Greece. Tel: 30-25310-39824. E-mail: cvlados@econ.duth.gr
}

Received: November 25, 2020

Accepted: December 24, 2020

Online Published: January 11, 2021

doi:10.5430/rwe.v12n2p1

URL: https://doi.org/10.5430/rwe.v12n2p1

\begin{abstract}
In economies where most firms are family-owned, there is a risk of poor management and problematic strategic and technological comprehension. Multiple cases prove the existence of a series of socio-economic pathologies in such firms that undermine an economy's ability to overcome economic crises through innovative and entrepreneurial thinking and adaptability. The paper aims to present the relationship between entrepreneurship and "development and crisis" from the perspective of Greece's current socio-economic crisis. It first analyzes the neo-Schumpeterian entrepreneurship theory and the structures that allow innovative and competitive models to appear and then links this context with Greece's case. The "Stra.Tech.Man" theoretical framework of physiological types of entrepreneurship is suggested as the analytical base for elaborating a local development policy instrument for economies where such less competitive businesses prevail.
\end{abstract}

Keywords: entrepreneurship, socio-economic crisis, Greek crisis, neo-Schumpeterian perspective, Stra.Tech.Man physiology, entrepreneurship types, less competitive firms, local development

\section{Introduction}

A vibrant discussion is underway as to how innovative firms can bring socio-economic development in today's Greece, which seems to enter a new development trajectory after the long-term recession that resulted from a structural socio-economic crisis (Koronis \& Vlados, 2019). Although Greece seems to be moving in the right direction today, with a highly skilled human workforce and with a banking sector working to improve their finances, at the same time, severe problems in Greek entrepreneurship appear to persist.

Positive socio-economic development occurs through innovative firms, predominantly. However, there are internal organizational "taboos" within Greek companies and industries, for which there is no extensive dialogue. For the most part, these organizational deficiencies hinder business performance (Xie \& Suh, 2014), even when the external environment is favorable and internal reforms assist in the right direction. In particular, in many Greek industries, a "shadow entrepreneurship" still exists and sometimes prevails (Williams \& Nadin, 2011). Entrepreneurs without the necessary funds and "collateral" are trying to survive by evading taxes, defying labor laws, and downgrading their product or service. Simultaneously, several tourist services are still at a comparatively low level of competitiveness, contrary to the widespread belief that Greece's tourist product is one of the most developed tourist products worldwide (Dimelli, 2017; Vasileiou et al., 2016).

Besides, in an economy where most firms are family-owned, there is an increased risk of poor management practice and problematic cooperation models. Multiple cases within large firms prove the existence of a series of organizational pathologies. In many European countries where there is a similar business structure (especially in Italy), there has recently been a fundamental shift in corporate governance and external relations. To this end, many small and medium-sized enterprises in the European South appear to be moving away from centralized structures (Mack \& Szulanski, 2017) and evolving into active players in the global market, whereas in Greece, such a transition 
does not seem to be the case. Still, it is a fact that all firms need medium-term to long-term strategies. Although a "myopic" approach to reforms by the Greek state, together with multiple institutional framework changes, has forced Greek firms to think in the short-term logic and, therefore, not plan and implement long-term strategies, a repositioning now seems necessary. Firms need to be always ready to invest in new projects and even change their basic tactics to survive. However, exports and successful strategies require relative stability, building brand reputation, and systematically investing in modern technologies (Love \& Roper, 2015). In other words, as the economic environment changes, all firms must adapt. Otherwise, the improvement in funding and the institutional framework will create temporary or anemic, or "inflated" growth. This development must come from upgraded firms by creating the structures in which visionary entrepreneurs can invest in exporting and innovative efforts, or else Greece will again experience an irregular cycle of internal growth only.

More profoundly, however, important structural questions arise. How does the concept of entrepreneurship relate to the development and crisis consequences? How can entrepreneurship help strengthen the Greek economy to find a new path of socio-economic development? These are the two main questions that this article will try to answer by reviewing the relevant literature, presenting the Greek firms' level of development, and proposing a repositioned economic policy-making framework.

This paper aims to link the Greek economic context with modern entrepreneurship theory and identify the structures that allow innovative-competitive models to emerge. A theoretical proposition that has been previously framed as "Stra.Tech.Man" is transferred into the context of economies dominated by small businesses and suffering from entrepreneurial pathologies. This articulation will present how entrepreneurship relates to the phenomenon of "development and crisis" under the perspective of Greece's current socio-economic crisis by following specific methodological steps. The paper first presents the foundations in business innovation theory and discusses its relationship with socio-economic crisis and development. It uses the Schumpeterian and neo-Schumpeterian contributions to the evolutionary dynamics of the firm. Next, it analyzes contemporary contributions to the Greek socio-economic system. Then, it discusses the socio-economic crisis issue, emphasizing the Greek case in the context of seeking an overall enhancement of the competitiveness and attractiveness of the socio-economic system. Subsequently, it outlines three "physiological" types of entrepreneurship that appear to be prevalent in Greece by utilizing the "Stra.Tech.Man" approach, which suggests that the innovative-competitive potential of socio-economic organizations comes from how they synthesize the spheres of strategy, technology, and management. Finally, it summarizes the findings, proposing a repositioned economic policy framework to strengthen entrepreneurship in Greece.

\section{Literature Review}

This section investigates the relevant literature of entrepreneurship and development by focusing on Greece's case, attempting a non-systematic approach to synthesize the existing knowledge, and suggesting a new theoretical framework (Snyder, 2019). The issues of development and crisis from a neo-Schumpeterian perspective are explored, focusing on how entrepreneurship evolves within a socio-economic system.

\subsection{Entrepreneurship, Development, and Crisis in neo-Schumpeterian Terms}

The study of entrepreneurship and the respective successful innovation introduced into the socio-economic system have their theoretical foundations primarily in Schumpeter's work (1942, 1939, 1934). Schumpeter (1942, pp. 82-83) first put the action of the innovative entrepreneur at the center of the capitalist process, arguing that "the fundamental impulse that sets and keeps the capitalist engine in motion comes from the new consumers' goods, the new methods of production or transportation, the new markets, the new forms of industrial organization that capitalist enterprise creates."

According to this observation, Schumpeter (1942, p. 31) argues that the capitalist system's evolution follows a steady course of constant changes due to innovation: "capitalist economy is not and cannot be stationary. Nor is it merely expanding in a steady manner. It is incessantly being revolutionized from within by new enterprise." This intrinsic revolution of the system is due to the profit-motivated entrepreneur, who causes constant upheavals in historically existing situations (he aspires to "build a personal empire"). In this context, Schumpeter (1939, p. 223) emphasizes the dialectically elevating behavior of the capitalist system where prosperity phases give their place to recessionary phases in an ever-transforming way. In this capitalist process, a new situation is always created, in a higher level of evolution, until bureaucratically-minded technocrats take over businesses, profits cease to exist, and thereby capitalism falls victim to its success.

The central explanatory power in this Schumpeterian scheme of development and crisis through innovation is the 
concept of "creative destruction." For Schumpeter (1942, pp. 81-86), the destruction of old forms and norms through business innovation can describe economic development's discontinuous nature. This continuous cycle of development and crisis is a dynamic and evolutionary process, in which most quasi-static analyses of quantities are relatively inadequate: "Dynamic analysis is the analysis of sequences in time. In explaining why a certain economic quantity, for instance a price, is what we find it to be at a given moment, it takes into consideration not only the state of other quantities at the same moment, as static theory does, but also their state at preceding points of time, and the expectations about their future values" (Schumpeter, 1942, p. 107).

On top of these observations focusing on the evolutionary logic, subsequent neo-Schumpeterian works appear gradually and begin to penetrate the deeper structural processes synthesized within firms' behaviors, in what is called the "evolutionary theory of the firm." The first work in this conceptual direction is by Nelson and Winter (1982). One of its central arguments is that the neoclassical maximization paradigm assumes that the firm is just an automatic transformer of inputs into outputs in a rational way, which is analytically inadequate. They argue that we can borrow biological analogies to the study of the firm. The firm is an "organism" that has organizational capabilities and exercises specific routines over time:

"We have argued in detail the view that organizational capabilities consist largely of the ability to perform and sustain a set of routines; such routines could be regarded as a highly structured set of 'habitual reactions' linking organization members to one another and to the environment. The tendency for such routines to be maintained over time plays in our theory the role that genetic inheritance plays in the theory of biological evolution" (Nelson \& Winter, 1982, p. 142).

Today, recent contributions to the firm's evolutionary theory and the development of entrepreneurship follow the Schumpeterian finding of the capitalist system's discontinuity through periodic development/crisis cycles due to innovation. For example, business evolution is a process of emergence rather than rational design (Nooteboom, 2008) as "heterogeneous" processes appear within the firms (Coad, 2010), which always have bounded rationality and limited learning capabilities (Etemad, 2017; Rahmeyer, 2010). Firms are socio-economic organizations of "biological-type" that express their individuality and behaviors and design their specific strategies to survive in their continually changing internal and external environment (Sirghi, 2014; Stoelhorst, 2010).

According to Hanusch and Pyka (2007), the neo-Schumpeterian perspective is about synthesizing the micro, meso, and macro levels analytically by exploring innovation and firms' learning behavior (micro-level), the structural and qualitative dynamics of industry (meso-level), and the articulation of international competitiveness (macro-level). In this sense, the institutional environment through the periodic change of the existing "paradigm" is a central analytical pillar (Acemoglu \& Robinson, 2012; Dosi, 1982; Kaldor, 2008; Perez, 2002, 2010). An institutional environment's ability to transform structurally through institutional innovations is another feature of the neo-Schumpeterian analysis (Pyka \& Nelson, 2018; Raffaelli \& Glynn, 2015).

Overall, socio-economic systems' evolution depends on the firms' innovative development that they can host and nurture. In particular, in today's era of crisis and restructuring of globalization (Vlados et al., 2018a), where global capitalism changes both qualitative and quantitative context drastically, the dialectical "diptych" of development and crisis co-exists in all socio-economic systems with the dynamics of knowledge and innovation that, ultimately, depend on the dynamics articulated by the firms (Figure 1). 


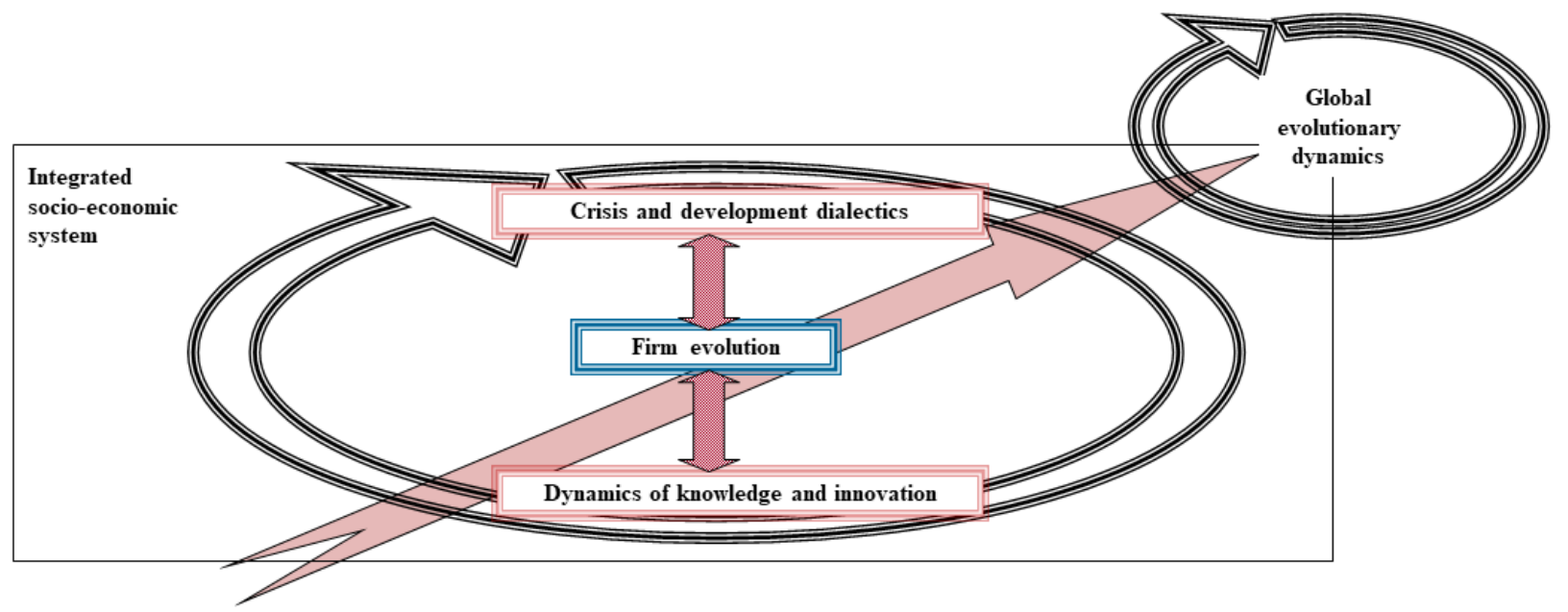

Figure 1 . The evolutionary cycle of socio-economic systems in globalization passes through the dynamics of firms

In conclusion, the neo-Schumpeterian theory places the dynamics of the firm at the center. To this end, it also borrows some of the analytical features of evolutionary biology. This analysis moves away from neoclassical maximization calculus, as the firm has routines and behaves like a "living organization" (Vlados, 2019b). In the neo-Schumpeterian perspective, all spaces and institutions evolve organically, making a socio-economic system competitive.

\subsection{Approaches to the Greek Crisis in the Literature}

This kind of approach to capitalist evolution as a perpetual cycle of development and crisis means that our world is not in balance, nor is it likely to be in the future, despite earlier optimistic forecasts (Fukuyama, 1992; Ohmae, 1999). During the current crisis and restructuring phase of globalization, the Greek socio-economic system is increasingly experiencing a negative performance in innovative entrepreneurship and competitiveness (Vlados et al., 2018b). In this sense, the Greek crisis makes up a profound structural transformation phenomenon.

Many relevant approaches address the Greek crisis from a macroeconomic perspective. For example, there is a study of the financial data of the Greek crisis, considering the swelling of public debt (Kouretas \& Vlamis, 2010), or the relatively weak regional position of Greece as a country of the European South (Kazemi \& Sohrabji, 2012; Magoulios \& Chouliaras, 2014). The criticisms of austerity policies applied to the weak Greek economy are also another common framework in analyzing the causes of the crisis (Andreou et al., 2017; Triantopoulos \& Staikouras, 2017), as well as the existence of a shadow economy associated with high levels of corruption (Bitzenis et al., 2016). Simultaneously, causes related to the Greek socio-economic system's weakness for real social and political development are also identified (Andrikopoulos \& Nastopoulos, 2015; Koutsoukis \& Roukanas, 2011; Skalkos, 2018).

Some approaches focus on the aspect of inadequate and less competitive entrepreneurship within the Greek socio-economic system. For example, Herrmann and Kritikos (2013) argue that Greece is not an innovation-intensive economy, as it has weak industrial growth and a large number of comparatively small firms. Vassiliadis and Vassiliadis (2014) highlight the succession problem in small and medium-sized Greek family-owned businesses, arguing that they experience issues in developing their human resources, which are exacerbated by the existence of bureaucracy and an unstable tax environment. Williams and Vorley (2015) take the view that the institutional system in Greece is deteriorating recently and is leading to an "entrepreneurship crisis," while Giannacourou et al. (2015) and Sainis et al. (2016) find structural problems within the Greek companies.

According to Kaplanoglou et al. (2016), Greece presents one of the most substantial tax gaps compared to other developed economies, indicating a strategic tax evasion on the part of small and medium-sized enterprises. Giotopoulos et al. (2017) note that Greek firms lack human capital and entrepreneurial training, while Giotopoulos and Vettas (2018) focus on how the Greek business system can be restructured towards a dynamic, extroverted, and export-oriented productive model. According to Kapitsinis (2019), finally, several firms' relocation to neighboring countries shows a necessity rather than an expansion strategy. 
In Greece, production factors are not particularly fertile and knowledge-oriented, while there is a relative absence of sophisticated labor in terms of market skills (Christopoulou \& Monastiriotis, 2016). Moreover, the Greek market is not a demanding one in terms of quality, and the difficulty of gaining a prominent exporting place among developed countries reflects this deficiency (Klonaris \& Agiangkatzoglou, 2017; Pitelis, 2012). Simultaneously, the knowledge and innovation environment seem weak and entrenched (Panagiotakopoulos, 2015), also reproducing cultural and demographic problems (Ifanti et al., 2014; Labrianidis \& Vogiatzis, 2013).

According to these analyses, it appears that the current socio-economic crisis in Greece, which has multilevel consequences (at the firm, industry, and national level), is not "coincidental." It is articulated in multiple conceptual and practical levels: socio-political, economic, cultural, and ideological, in the particular contexts of today's crisis and restructuring of global capitalism (Caron, 2020).

\subsection{Competitiveness and Attractiveness}

Understanding the multilevel crisis of entrepreneurship requires a repositioned view of the development phenomenon from a historical and multidimensional perspective. In practice, economic development differs from economic growth. The economic growth approach usually bypasses socio-economic factors since it sees economic development as a mechanistic outcome of a growing economy (Arndt, 1981; Chartier, 2004; Coméliau, 1994; Schubert \& Zagamé, 1998). Quite often, in terms of economic growth, market flows appear sufficient to study economic progress and development, while socio-institutional structures are usually bypassed (Dragan \& Demetrescu, 1988; Georgescu-Roegen, 1971). This mechanistic interpretation considers economics a mechanical science, which should not deviate towards ideological and political directions (Foray, 2009; Zaccaï, 2002).

For Brinkman (1995), science has specific paradigmatic boundaries, and, in this context, a leveling based on the logistic growth curve can be the only outcome of economic growth. Brinkman postulates that economic evolution needs both growth (reproduction and replication) and development (mutation and transformation). Therefore, economic development and economic growth are different concepts, with economic growth usually reflected in national or per capita income and GDP increases, while economic development in the quality-of-life improvements, poverty reduction, and structural economic changes (Nnadozie \& Jerome, 2019). According to Acemoglu (2012), economic growth is an exciting sub-area of economics, although the problem of economic development remains a major one for humanity at large and economics as a science.

Although economic development is not possible in the long term without simultaneous economic growth, the two concepts are distinct in investigative terms. The "conventional" theorization of economic growth only studies cumulative quantities, whereas economic development refers to profound, qualitative and structural, socio-economic transformations (Alcouffe \& Ferrari, 2008; Chiras, 1995; Hosseini, 2003). In the ever-transforming context of economic science, standard neoclassical economics is still attached to the belief that critical development issues, such as poverty, technological change, political power, crisis, innovation, and other socio-economic dimensions, lie externally to the scope of "pure" economics (Nelson et al., 2018; Nelson \& Winter, 1974; Vlados, 2019c). On the contrary, contemporary evolutionary and neo-Schumpeterian theorizations perceive development as a historic, multiform, and dynamic process of both qualitative transformations, implemented within an ever-altering framework of evolving social forms and political priorities (Andersen, 2009; Boulding, 1981; Chatzinikolaou \& Vlados, 2019; Dopfer \& Nelson, 2018; Pyka \& Nelson, 2018; Rahmeyer, 2016; Winter, 2006).

As we have seen, a potential point of enrichment of today's economic science lies at the micro-level of the firm's dynamics and the meso-level of economic sectors and localities. In this sense, the Greek crisis problem begins with the deficiency in multilevel competitiveness (Esser et al., 2013; Peneder, 2017). All socio-economic players in the global evolutionary process reproduce their comparative strengths and weaknesses in a "correlated" rather than an "absolute" manner, and, therefore, being better than your competitors is an ongoing process (Vlados, 2019a). In this context, each socio-economic organization (an individual, a business, a region, or a nation) may be more competitive than their counterparts based on a common goal (Balkyte \& Tvaronavičienè, 2010). A socio-economic organization's competitiveness means to survive and thrive in the external global environment's evolving conditions (Vlados \& Chatzinikolaou, 2019c).

Many definitions of competitiveness refer to a nation's ability to produce and deliver goods to international markets by increasing the citizens' real income (Boltho, 1996). However, studying competitiveness in terms of entrepreneurship at the micro-level and meso-level enriches this national competitiveness analysis. Firm-level competitiveness is the firm's ability to perform better than its competitors and constitutes the "cellular" process. Meso-competitiveness occurs at the level of firms' agglomerations, mostly at local or regional spaces (Porter, 1998). In this context, today, competitiveness is a multilevel synthesis product that involves all levels of space, in their global perspective (Figure 2). 


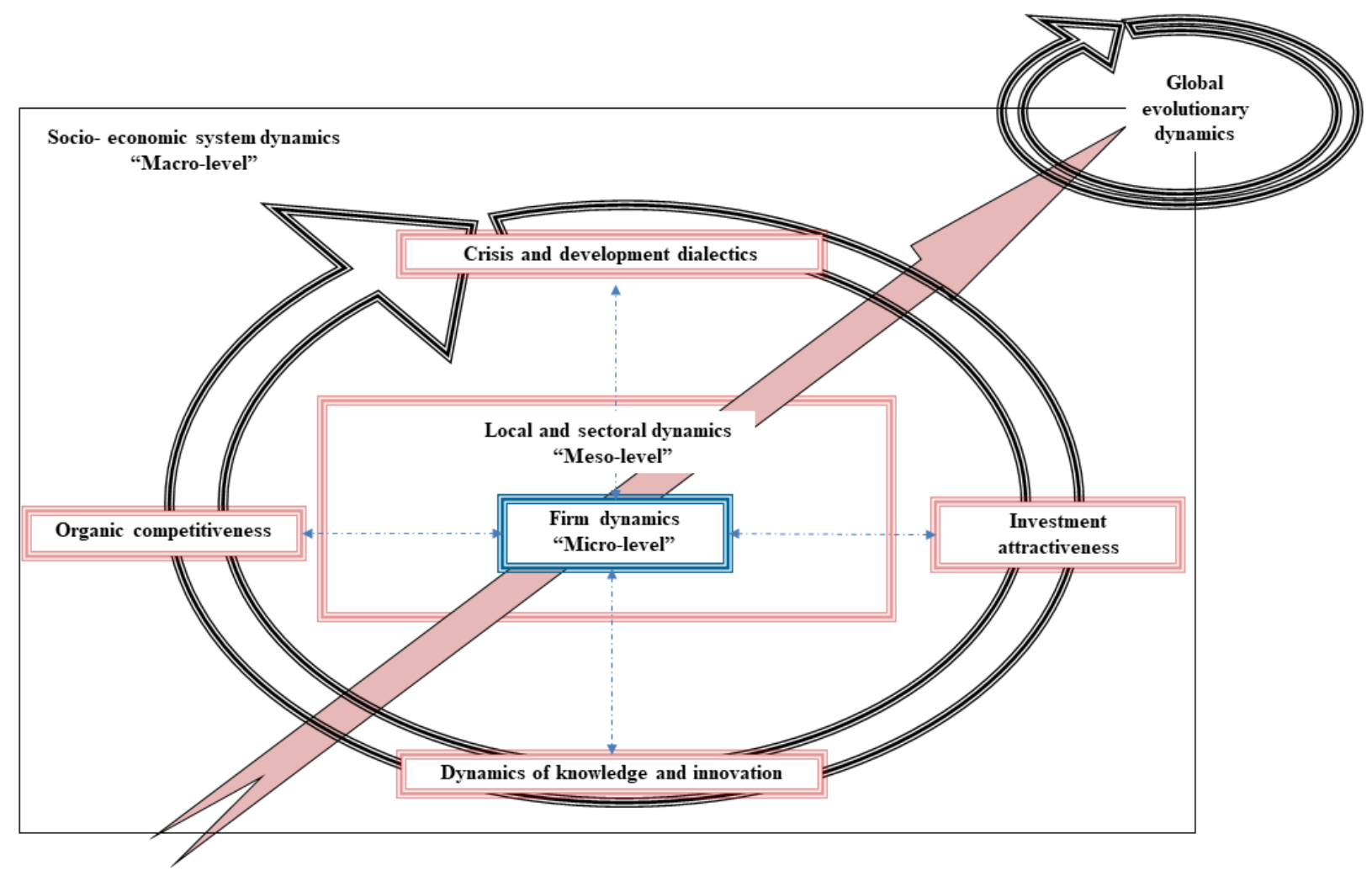

Figure 2. Competitiveness and attractiveness as structural development factors at the different socio-economic systems

This structural approach to multilevel "micro-meso-macro" competitiveness (Dopfer, 2011; Dopfer et al., 2004) can help us understand that socio-economic development collectively consists of four dynamics: the dynamics of knowledge and innovation; the dialectic of crisis and development with the continued emergence of new socio-economic forms; the dynamics of investment attractiveness; and the dynamics of "organic" competitiveness created by all the socio-economic system's (or "competitiveness web") tangible and intangible resources (Vlados, 2019d).

Investment attractiveness is a critical pillar in defining a competitiveness framework that links the entire socio-economic system's macro-dynamics, the regional or local space's inter-sectoral meso-dynamics, and the firm's micro-level entrepreneurial dynamics (Aydalot, 1986; Delapierre et al., 2000). In this sense, socio-economic development in today's era of globalization presupposes a socio-economic system's ability to attract and assist in establishing business interests (at local, national, and supranational levels).

Moreover, this doublet of "attractiveness-competitiveness" presupposes the existence of mechanisms to help create a competitive advantage in terms of locality (Algan et al., 2013; Bloom et al., 2012; Bougette \& Charlier, 2016). Maintaining the attractiveness of business interest requires the socio-economic space to remain competitive by meeting the international aspirations of the firms it hosts. As a result, the Greek socio-economic crisis is primarily due to a relative lack of competitiveness found at the micro-level of the hosting firms' innovative potential. In Greece, most firms appear to "be governed" by structural deficiencies, stemming from their extremely low competitiveness, which derives from the way they articulate (or do not articulate) their innovation. The next section examines the problem of structural idiosyncrasies of the Greek socio-economic business ecosystem.

\section{Structural Dimensions and Peculiarities in Greek Entrepreneurship}

Although the dynamics of globalization lean on and affect all socio-economic systems and organizations, leading to an increasingly deeper homogenization, the forces of cultural heterogeneity and diversity are reinforced at different edges of the world (Ladhari et al., 2015; Roudometof, 2014; Scherer et al., 2013). To this end, according to Vlados $(2012,2004)$, the Greek entrepreneurial ecosystem hosts firms of different (idiosyncratic) "physiology" and structure: 
that is, the firms operating in Greece do not all belong to the same "species" of entrepreneurship. Specifically, Greek firms "think" and act based on three distinct "Stra.Tech.Man" physiologies, that is, in the way they evolve the inner dialectical spheres of their strategy, technology, and management. The three "Stra.Tech.Man" questions that govern these organizations (and every other socio-economic organization) are the following:

i. Strategy: "where am I, where am I going, how do I go there, and why?"

ii. Technology: "how do I draw, create, synthesize, spread, and reproduce the means of my work and know-how, and why?"

iii. Management: "how do I use my available resources, and why?" (Figure 3)

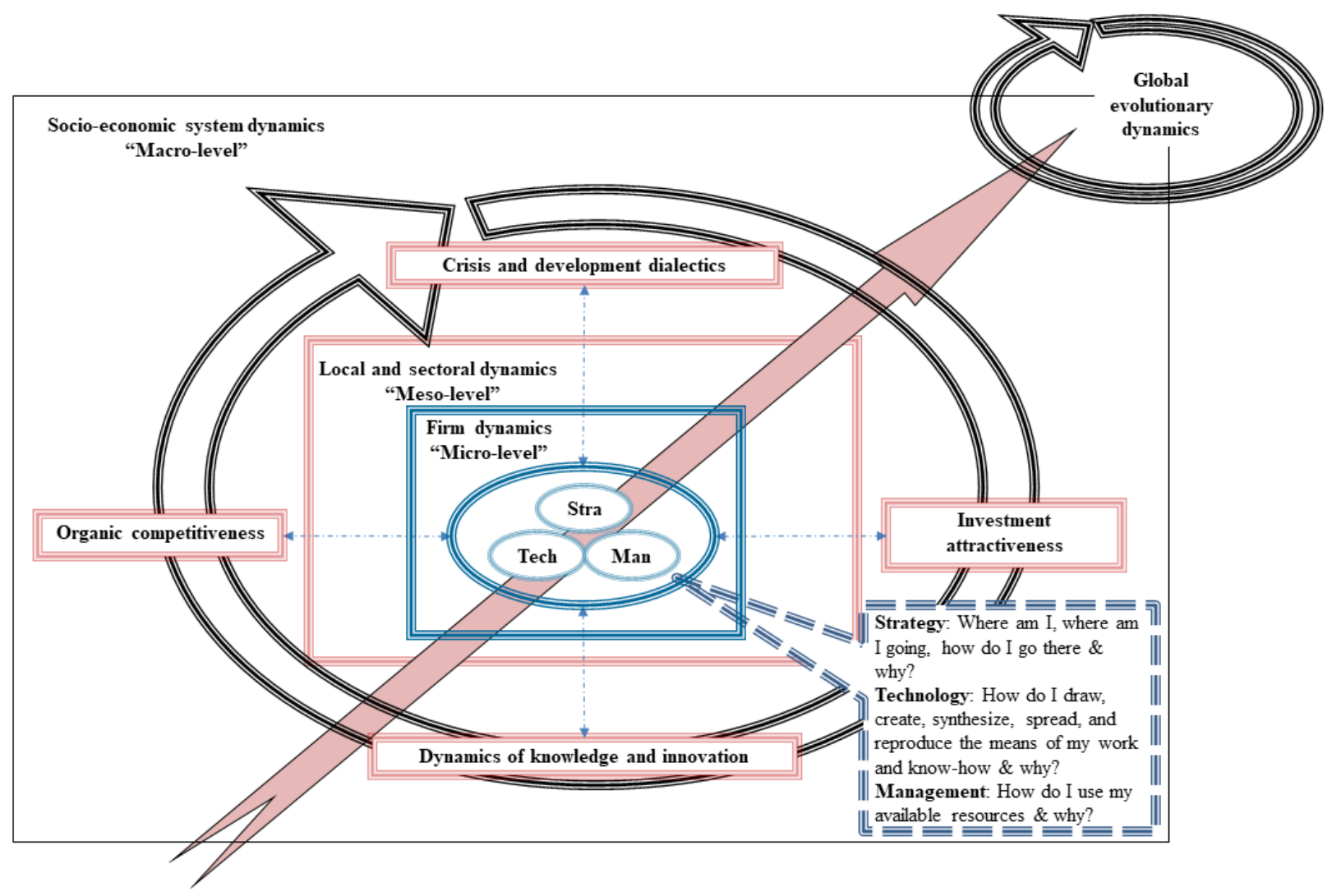

Figure 3. The evolutionary Stra.Tech.Man "physiology" of the firm at the center of the socio-economic system's evolutionary trajectory

Analyzed in a spatially and historically defined framework, the ways socio-economic organizations compose the three Stra.Tech.Man spheres also specify the socio-economic system's innovation potential, competitiveness, attractiveness, and overall development and crisis potential. In other words, the sophistication level of innovative entrepreneurship in terms of Stra.Tech.Man determines the overall evolutionary trajectory of the socio-economic system in globalization.

According to the Stra.Tech.Man "physiological" typology developed by Vlados (2004), there are three major categories of entrepreneurial development in Greece, classified as "monad-centered," "massive," and "flexible" entrepreneurship. It turns out that the Greek socio-economic system's low competitiveness is due to the existence of "monad-centered" firms, which constitute the overwhelming majority even today (Vlados \& Chatzinikolaou, 2019a, 2019b):

- In terms of strategy, "monad-centered" firms exploit an instinctive approach. At the technology level, they choose tools (in a broad sense) sporadically, while at a management level, the everyday experience of 
market practice prevails.

- On the contrary, "massive" firms follow a "mechanistic" logic in articulating their strategy, utilize their technology linearly, and base their management on rigorous specialization.

- The advanced forms of entrepreneurship, the "flexible" ones, think in an evolutionarily strategic way while their technology is increasingly network-based and modern, followed by multilevel and participatory management, both bottom-up and top-down.

\section{1 "Monad-Centered" Firms}

In terms of strategy, a "monad-centered" firm's core logic (Miller et al., 2001; Nieto et al., 2015; Siakas et al., 2014; Vlados, 2004) is instinctive since a strategic systematization is absent. It uses this instinct to pursue a "short-sighted" immediate profit by tending to avoid risk-taking. At the same time, business planning is usually an informal process in which the business owner is the dominant figure. Besides, this firm tracks its internal and external environment superficially, without clear and systematic methods. More generally, this firm's "strategic planning" follows the rationale of immediate profitability with a repetitive nature, while the overall strategic concept presents a peculiarly mixed framework of opportunism and conservatism.

In terms of technology, the "monad-centered" firm exploits the technological opportunities that lie ahead of it sporadically, in the absence of a systematic framework for identifying its evolving knowledge environment. Technology creation is minimal internally, mainly expressed as "better standardization," technology adoption seems like an obstacle to overcome, and the diffusion and application of technology are limited to specific actions that usually the business owner undertakes solely. Finally, technological evaluation is sporadic as the firm performs low value-added projects in terms of technology.

In terms of management, the core logic of practical experience runs throughout all the firm's managerial levels. The organizational design focuses on immediate and short-term solutions to pressing problems, with role overlaps and the absence of a written organization chart. Business staffing is usually based on the recruitment of employees with practical experience in the field, while the development of human resources is considered unnecessary to the extent that "the business must survive" in the "adverse" conditions of competition. In this context, motivation assumes a character of trust in this firm that stems from a traditional and peculiar type of "paternalism" inspired by the business owner and, therefore, leadership is at the sole responsibility of the "boss." Finally, the owner's willingness defines in this type of firm how things are controlled, while communication and coordination are usually activated after the problem occurs and becomes a pressing one.

\section{2 "Massive" Firms}

In terms of strategy, the massive firm's core logic (Belasco, 1991; Lee \& Edmondson, 2017; Moss Kanter, 2013; Vlados, 2004) follows mechanistic effectiveness, with the overall strategic focus expressed as the accomplishment of quantifiable projects. In this way, the massive firm's business plan is "strictly systematic" and, to a certain extent, sufficiently bureaucratic, leading to tracking the external environment from a quasi-static perspective that is unable to foresee unexpected changes. This firm analyzes the internal environment with precise controls that measure operational efficiency and performance. In this context, strategic analysis is a matter primarily for top executives and, secondarily, for shareholders, usually taking the form of an "introverted" process that should not go beyond the firm's internal boundaries.

In terms of technology, it follows a linear logic mostly, focusing on the systematic exploitation of existing technologies in the internal value chain. Technology acquisition takes small and quantifiable steps, while only incremental and measurable performance additions lead to exploiting modern technologies. The adoption and diffusion of technology are mechanistic, as they usually involve specific functional segments of the firm, while the implementation of technology is under the senior management's responsibility, at the top of the hierarchy. Finally, technological evaluation resembles a rally whereby added quantitative improvements are the primary criterion of success.

The core logic of strict specialization runs throughout all the "massive" firms' hierarchical management levels. Management planning concerns long-term quantitative goals and rules through a "generally rigid" hierarchy reflected in a detailed organization chart. In this context, the massive firm's recruitment focuses on searching for a qualified specialist with limited needs since human resource development focuses on specific operational areas. The aspect of motivation in this type of firm has a "purely" quantitative and predetermined nature of economic incentives, while leadership is rigorous with clear routines and rules. The centrally designed controlling is implemented with formal reports, while coordination and communication have a top-down character that usually occurs linearly. 


\section{3 "Flexible" Firms}

In terms of strategy, a flexible firm's core logic (Deming, 1982; Englehardt \& Simmons, 2002; Nandakumar et al., 2014; Vecchiato, 2015; Vlados, 2004) is of evolutionary conception, which views the business environment as a dynamic whole. Business planning at this level considers and, at the same time, composes various social and economic dimensions as they transform over time. The study of the environments (internal, external, and meso-sectoral) is "organic" by taking historical back-and-forth comparative data since it is an active co-creator of developments. This firm's strategic analysis is functionally multilevel, working "along the length and width" of the business in the constant pursuit of business evolution. The "flexible" firm focuses not only on its short- and long-term profitability but also on combining the two and achieving its bold vision.

The flexible firm follows a networking technological perspective, focusing on interactive technological data utilization and enabling dynamic and continuous technology acquisition. At the level of technology adoption, the "flexible" firm is well developed and durable as it focuses on continually evolving its quality dimensions while striving to create technology organically. It seeks to integrate technology into the organization between individuals and groups simultaneously. The diffusion of technology is inter-departmental and integrated, while technological application focuses on this inter-departmental concept since a business division's creativity can extend to the rest of the organization. In conclusion, a "flexible" firm evaluates its technological endeavor with a lens of overall technical efficiency, integrating all the relevant quality dimensions.

In terms of management, the core logic of participation is a shared focus on the flexible firm. A continuous quality improvement belief drives management planning through the integration of short and long-term goals. Simultaneously, the organization follows a decentralized logic where partial operational teams are autonomous under the condition that they work under the shared vision. Recruitment focuses on finding the creative and hardworking partner, with human resource development following a cognitive enhancement rationale across all organizational departments. At this level, motivation has an idealistic and long-term character, with multi-faceted leadership that fosters open discussion and consensus in decisions. To this end, decentralized controlling is sought via the audit of partial projects and the employee's self-evaluation. Finally, the flexible firm achieves communication and coordination at all the organization chart's levels and "hierarchies" while disseminating information through interactive networks.

\subsection{Critical Conclusions}

These three types of Stra.Tech.Man physiologies show that there are structural reasons why some firms (socio-economic organizations) stand out as compared to others. They reproduce their innovative potential in the system that hosts them and, in this case, in a relatively weak innovative Greek socio-economic system. The fact that the "monad-centered" or "family-centered" firms are the majority (for several years) in Greece points to the reproduction and dominance of the least systematic way of doing business, which does not include many elements of capitalist efficiency. They keep surviving while they are lagging in competitiveness because the Greek socio-economic system favors them.

The crucial issue for Greek entrepreneurship is the adaptation to today's conditions of increasing competition in globalization, which seems increasingly difficult in the current pandemic crisis of COVID-19 and the subsequent socio-economic changes at the global level (United Nations, 2020). It seems that the "monad-centered" entrepreneurial physiology has to hybridize (Battilana \& Dorado, 2010; Ghosh \& Ray, 2017) to more massive or flexible forms of entrepreneurship by increasing the potential for innovation and knowledge. In this case, the overall competitiveness and attractiveness of the Greek socio-economic system would improve.

\section{Concluding Remarks: Proposals for the Structuration of Entrepreneurship-Enhancement Mechanisms in Greece}

This article highlighted entrepreneurship as a crucial factor in the development and crisis of socio-economic systems in today's changing globalization conditions by examining critical contributions to entrepreneurship analysis. After presenting structural problems reproduced by the Greek socio-economic system in the domestic entrepreneurship, it presented a "physiological" typology of Greek firms, based on the way these perform in terms of strategy, technology, and management internally (the "Stra.Tech.Man approach").

The Greek socio-economic system reproduces an idiosyncratic type of business physiology: the "monad-centered" one. In this context, most Greek firms articulate their strategy based on instinctive choices and exploit only sporadically technological tools and expertise, and management solely follows the inefficient, in broad terms, everyday practical experience. Consequently, competitiveness improvement, especially for small, medium-sized, and 
family-focused enterprises, seems to be a priority for a new competitiveness policy in conditions of socio-economic crisis (Vlados \& Chatzinikolaou, 2020). According to Vlados and Chatzinikolaou (2019d), "Local Development and Innovation Institutes" are one such policy that the Greek government could implement directly in the Greek regions (Figure 4).

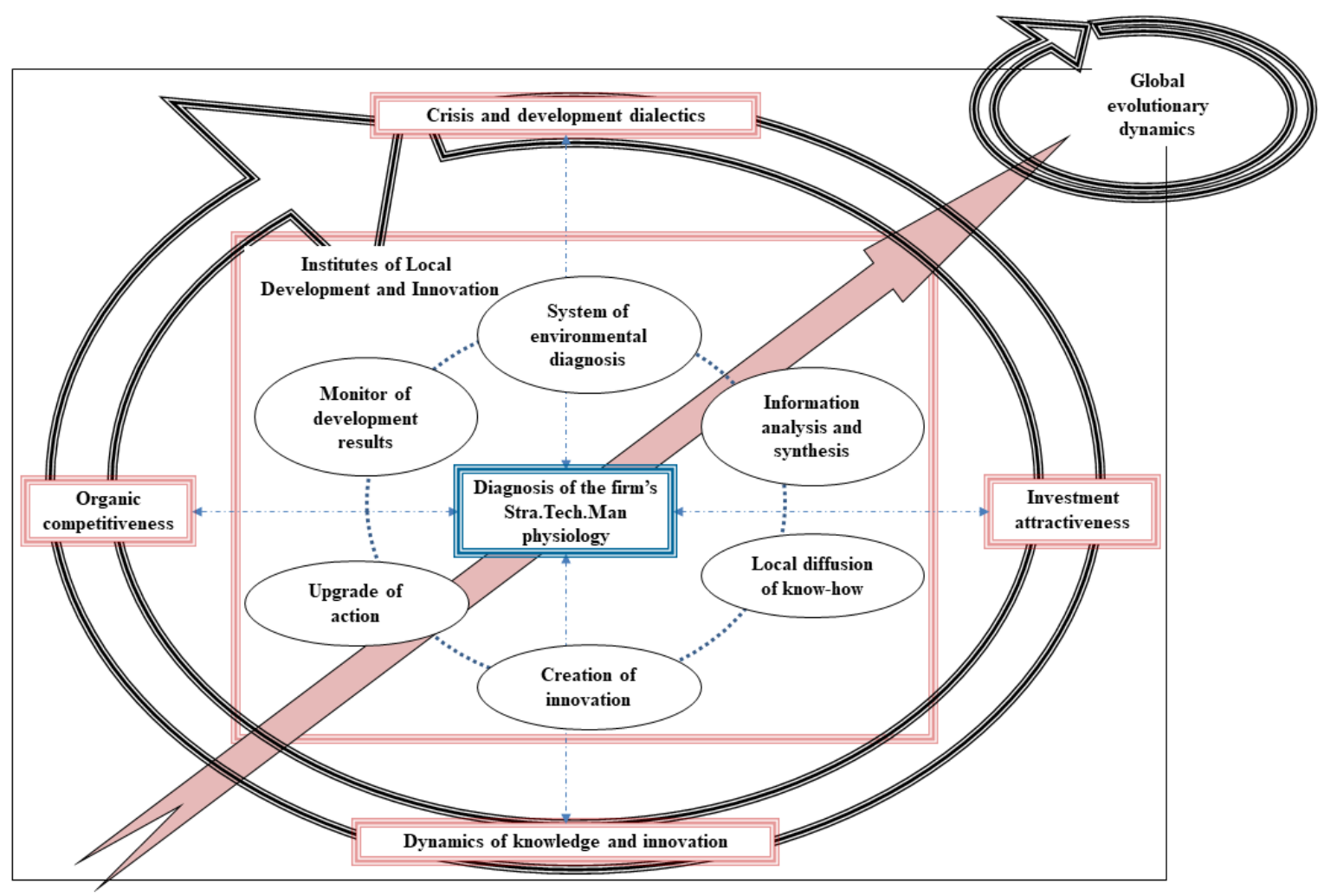

Figure 4. Local Development and Innovation Institutes in the context of the Greek socio-economic system. Based on Vlados and Chatzinikolaou (2019d)

These Institutes could connect local actors (at the level of business ecosystems, business clusters, official regions) who until yesterday were uncoordinated and incapable of supporting coordinated development, such as local government, universities, and local businesses (Carayannis \& Campbell, 2010; Etzkowitz \& Leydesdorff, 1995). These development mechanisms, aiming to strengthen and stimulate entrepreneurship potential, could focus primarily on the diagnosis of business physiology in "Stra.Tech.Man terms."

They could follow a cycle of six successive steps, in which the priority is building a system of environmental diagnosis through field research on the locally established entrepreneurship. The analysis and synthesis of the information could follow, which clarifies the process of partnership, networking, coordination, and decision-making for local businesses, suggesting and evaluating current investment opportunities. The mechanism could then focus on local diffusion of knowledge through business forums, networking processes, and educational interventions, such as scientific workshops. Next, it could create innovation and upgrade local entrepreneurship action by direct consulting, advising, and training in Stra.Tech.Man terms. Finally, this mechanism could track development results by collecting, configuring, and announcing data to the relevant bodies.

\section{References}

Acemoglu, D. (2012). Introduction to economic growth. Journal of Economic Theory, 147(2), 545-550. https://doi.org/10.1016/j.jet.2012.01.023

Acemoglu, D., \& Robinson, J. A. (2012). Why nations fail: The origins of power, prosperity, and poverty. Crown New York, US: Crown Publications. https://doi.org/10.1355/ae29-2j

Alcouffe, A., \& Ferrari, S. (2008). Growth versus development from Schumpeter to Georgescu-Roegen. 12th Annual 
Conference of the European Society for the history of economic thought, Prague.

Algan, Y., Cahuc, P., \& Shleifer, A. (2013). Teaching practices and social capital. American Economic Journal: Applied Economics, 5(3), 189-210. https://doi.org/10.1257/app.5.3.189

Andersen, E. S. (2009). Schumpeter's evolutionary economics: A theoretical, historical and statistical analysis of the engine of capitalism. London, UK; New York, US: Anthem Press. https://doi.org/10.7135/UPO9781843313359

Andreou, A., Andrikopoulos, A., \& Nastopoulos, Ch. (2017). Chapter 1 - Debt markets, financial crises, and public finance in the Eurozone: Action, structure, and experience in Greece. In F. Economou, K. Gavriilidis, G. N. Gregoriou, \& V. Kallinterakis (Eds.), Handbook of investors' behavior during financial crises (pp. 3-28). London, UK: Academic Press. https://doi.org/10.1016/B978-0-12-811252-6.00001-3

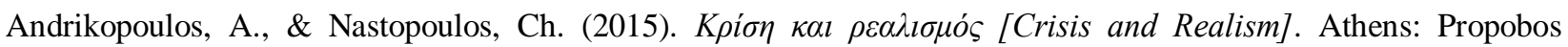
Publications.

Arndt, H. W. (1981). Economic development: A semantic history. Economic Development and Cultural Change, 29(3), 457-466. https://doi.org/10.1086/451266

Aydalot, P. (1986). Milieux innovateurs en Europe. Paris: GREMI.

Balkytė, A., \& Tvaronavičienè, M. (2010). Perception of competitiveness in the context of sustainable development: Facets of "sustainable Competitiveness." Journal of Business Economics and Management, 11(2), 341-365. https://doi.org/10.3846/jbem.2010.17

Battilana, J., \& Dorado, S. (2010). Building sustainable hybrid organizations: The case of commercial microfinance organizations. Academy of Management Journal, 53(6), 1419-1440. https://doi.org/10.5465/amj.2010.57318391

Belasco, J. A. (1991). Teaching the elephant to dance: The manager's guide to empowering change. New York, US: Plume.

Bitzenis, A., Vlachos, V., \& Schneider, F. (2016). An exploration of the Greek shadow economy: Can its transfer into the official economy provide economic relief amid the crisis?. Journal of Economic Issues, 50(1), 165-196. https://doi.org/10.1080/00213624.2016.1147918

Bloom, N., Sadun, R., \& Van Reenen, J. (2012). The organization of firms across countries. The Quarterly Journal of Economics, 127(4), 1663-1705. https://doi.org/10.1093/qje/qje029

Boltho, A. (1996). The assessment: International competitiveness. Oxford Review of Economic Policy, 12(3), 1-16. https://doi.org/10.1093/oxrep/12.3.1

Bougette, P., \& Charlier, C. (2016). La difficile conciliation entre politique de concurrence et politique industrielle: Le soutien aux énergies renouvelables. Revue économique, 67(HS1), 185. https://doi.org/10.3917/reco.hs01.0185

Boulding, K. E. (1981). Evolutionary economics. London, UK: Sage Publications.

Brinkman, R. (1995). Economic growth versus economic development: Toward a conceptual clarification. Journal of Economic Issues, 29(4), 1171-1188. https://doi.org/10.1080/00213624.1995.11505746

Carayannis, E., \& Campbell, D. (2010). Triple helix, quadruple helix and quintuple helix and how do knowledge, innovation and the environment relate to each other? A proposed framework for a trans-disciplinary analysis of sustainable development and social ecology. International Journal of Social Ecology and Sustainable Development (IJSESD), 1(1), 41-69. https://doi.org/10.4018/jsesd.2010010105

Caron, J.-F. (2020). The resurgence of the nation-state and the future of globalization. In J.-F. Caron (Ed.), A sketch of the world after the COVID-19 crisis: Essays on political authority, the future of globalization, and the rise of China (pp. 23-39). Singapore: Springer. https://doi.org/10.1007/978-981-15-7768-0_3

Chartier, D. (2004). Aux origines des flous sémantiques du développement durable: Une lecture critique de la Stratégie mondiale de la conservation de la nature. Ecologie \& politique, $29(2), 171$. https://doi.org/10.3917/ecopo.029.0171

Chatzinikolaou, D., \& Vlados, Ch. (2019). Schumpeter, neo-Schumpeterianism, and Stra.Tech.Man evolution of the firm. Issues in Economics and Business (International Economics and Business), 5(2), 80-102. https://doi.org/10.5296/ieb.v5i2.16097

Chiras, D. D. (1995). Principles of sustainable development: A new paradigm for the twenty first century. Journal of 
Environmental Science and Health, Part C, 13(2), 143-178. https://doi.org/10.1080/10590509509373475

Christopoulou, R., \& Monastiriotis, V. (2016). Public-private wage duality during the Greek crisis. Oxford Economic Papers, 68(1), 174-196. https://doi.org/10.1093/oep/gpv054

Coad, A. (2010). Neoclassical vs evolutionary theories of financial constraints: Critique and prospectus. Structural Change and Economic Dynamics, 21(3), 206-218. https://doi.org/10.1016/j.strueco.2010.05.003

Coméliau, C. (1994). Développement du développement durable, ou blocages conceptuels?. Revue Tiers Monde, 35(137), 61-76. https://doi.org/10.3406/tiers.1994.4850

Delapierre, M., Moati, P., \& Mouhoud, E. M. (2000). Connaissance et mondialisation. Paris: Economica.

Deming, E. W. (1982). Out of crisis. Cambridge, MA, US: Massachusetts Institute of Technology.

Dimelli, D. P. (2017). The effects of tourism in Greek insular settlements and the role of spatial planning. Journal of the Knowledge Economy, 8(1), 319-336. https://doi.org/10.1007/s13132-016-0364-x

Dopfer, K. (2011). The origins of meso economics: Schumpeter's legacy and beyond. Journal of Evolutionary Economics, 22(1), 133-160. https://doi.org/10.1007/s00191-011-0218-4

Dopfer, K., \& Nelson, R. (2018). The evolution of evolutionary economics. In R. Nelson (Ed.), Modern evolutionary economics: An overview (pp. 208-229). Cambridge, UK: Cambridge University Press. https://doi.org/10.1017/9781108661928.007

Dopfer, K., Foster, J., \& Potts, J. (2004). Micro-meso-macro. Journal of Evolutionary Economics, 14(3), 263-279. https://doi.org/10.1007/s00191-004-0193-0

Dosi, G. (1982). Technological paradigms and technological trajectories: A suggested interpretation of the determinants and directions of technical change. Research Policy, 11(3), 147-162. https://doi.org/10.1016/0048-7333(82)90016-6

Dragan, J. C., \& Demetrescu, M. C. (1988). Entropy and bioeconomics-The new paradigm Nicholas Georgescu-Roegen. International Journal of Social Economics, 15(7), 81-84. https://doi.org/10.1108/eb014114

Englehardt, C. S., \& Simmons, P. R. (2002). Organizational flexibility for a changing world. Leadership \& Organization Development Journal, 23(3), 113-121. https://doi.org/10.1108/01437730210424057

Esser, K., Hillebrand, W., Messner, D., \& Meyer-Stamer, J. (2013). Systemic competitiveness: New governance patterns for industrial development. Routledge. https://doi.org/10.4324/9781315036465

Etemad, H. (2017). Towards an emerging evolutionary life-cycle theory of internationalized entrepreneurial firms: From born globals to borderless firms?. Journal of International Entrepreneurship, 15(2), 111-120. https://doi.org/10.1007/s10843-017-0204-5

Etzkowitz, H., \& Leydesdorff, L. (1995). The triple helix -- University-Industry-Government relations: A laboratory for knowledge based economic development. EASST Review, 14(1), 14-19.

Foray, D. (2009). L'économie de la connaissance. Paris: La Découverte.

Fukuyama, F. (1992). The end of history and the last man. New York: The Free Press.

Georgescu-Roegen, N. (1971). The entropy law and the economic process. Cambridge, MA: Harvard University Press.

Ghosh, A., \& Ray, S. (2017). Theorizing "strategic transition towards organizational hybridism": Action research with CINI India. Academy of Management Proceedings, 2017(1), 15024. https://doi.org/10.5465/AMBPP.2017.139

Giannacourou, M., Kantaraki, M., \& Christopoulou, V. (2015). The perception of crisis by Greek SMEs and its impact on managerial practices. Procedia - Social and Behavioral Sciences, 175, 546-551. https://doi.org/10.1016/j.sbspro.2015.01.1235

Giotopoulos, I., \& Vettas, N. (2018). Economic crisis and export-oriented entrepreneurship: Evidence from Greece. Managerial and Decision Economics, 39(8), 872-878. https://doi.org/10.1002/mde.2976

Giotopoulos, I., Kontolaimou, A., \& Tsakanikas, A. (2017). Antecedents of growth-oriented entrepreneurship before and during the Greek economic crisis. Journal of Small Business and Enterprise Development, 24(3), 528-544. https://doi.org/10.1108/JSBED-01-2017-0003 
Hanusch, H., \& Pyka, A. (2007). Principles of neo-Schumpeterian economics. Cambridge Journal of Economics, 31(2), 275-289. https://doi.org/10.1093/cje/bel018

Herrmann, B., \& Kritikos, A. S. (2013). Growing out of the crisis: Hidden assets to Greece's transition to an innovation economy. IZA Journal of European Labor Studies, 2(1), 14. https://doi.org/10.1186/2193-9012-2-14

Hosseini, H. (2003). Why development is more complex than growth: Clarifying some confusions. Review of Social Economy, 61(1), 91-110. https://doi.org/10.1080/0034676032000050329

Ifanti, A. A., Argyriou, A. A., Kalofonou, F. H., \& Kalofonos, H. P. (2014). Physicians' brain drain in Greece: A perspective on the reasons why and how to address it. Health Policy, 117(2), 210-215. https://doi.org/10.1016/j.healthpol.2014.03.014

Kaldor, M. (2008, October 31). Crisis as prelude to a new Golden Age. OpenDemocracy. Retrieved November 25th, 2020, from https://www.opendemocracy.net/en/crisis-as-prelude-to-a-new-golden-age/

Kapitsinis, N. (2019). The impact of economic crisis on firm relocation: Greek SME movement to Bulgaria and its effects on business performance. GeoJournal, 84(2), 321-343. https://doi.org/10.1007/s10708-018-9863-6

Kaplanoglou, G., Rapanos, V. T., \& Daskalakis, N. (2016). Tax compliance behaviour during the crisis: The case of Greek SMEs. European Journal of Law and Economics, 42(3), 405-444. https://doi.org/10.1007/s10657-016-9547-y

Kazemi, H., \& Sohrabji, N. (2012). Contagion in Europe: Examining the PIIGS crisis. International Advances in Economic Research, 18(4), 455-456. https://doi.org/10.1007/s11294-012-9366-z

Klonaris, S., \& Agiangkatzoglou, A. (2017). Competitiveness of Greek virgin olive oil in the main destination markets. British Food Journal, 120(1), 80-95. https://doi.org/10.1108/BFJ-07-2016-0331

Kouretas, G., \& Vlamis, P. (2010). The Greek crisis: Causes and implications. Panoeconomicus, 57(4), 391-404. https://doi.org/10.2298/PAN1004391K

Koutsoukis, N.-S., \& Roukanas, S. (2011). The Greek crisis that should have been avoided. Scientific Bulletin Economic Sciences, 10(1), 21-27.

Labrianidis, L., \& Vogiatzis, N. (2013). Highly skilled migration: What differentiates the 'brains' who are drained from those who return in the case of Greece?. Population, Space and Place, 19(5), 472-486. https://doi.org/10.1002/psp.1726

Ladhari, R., Souiden, N., \& Choi, Y.-H. (2015). Culture change and globalization: The unresolved debate between cross-national and cross-cultural classifications. Australasian Marketing Journal (AMJ), 23(3), 235-245. https://doi.org/10.1016/j.ausmj.2015.06.003

Lee, M. Y., \& Edmondson, A. C. (2017). Self-managing organizations: Exploring the limits of less-hierarchical organizing. Research in Organizational Behavior, 37, 35-58. https://doi.org/10.1016/j.riob.2017.10.002

Love, J. H., \& Roper, S. (2015). SME innovation, exporting and growth: A review of existing evidence. International Small Business Journal, 33(1), 28-48. https://doi.org/10.1177/0266242614550190

Mack, D. Z., \& Szulanski, G. (2017). Opening up: How centralization affects participation and inclusion in strategy making. Long Range Planning, 50(3), 385-396. https://doi.org/10.1016/j.lrp.2016.08.004

Magoulios, G., \& Chouliaras, V. (2014). The repercussions of the financial crisis (2008) on the foreign trade between Greece and the Balkan countries (BCs). In A. Karasavvoglou \& P. Polychronidou (Eds.), Economic crisis in Europe and the Balkans (pp. 51-64). Heidelberg, Germany: Springer International Publishing. https://doi.org/10.1007/978-3-319-00494-5_4

Miller, N. J., McLeod, H., \& Ob, K. Y. (2001). Managing family businesses in small communities. Journal of Small Business Management, 39(1), 73-87. https://doi.org/10.1111/0447-2778.00007

Moss Kanter, R. (2013). Supercorp: How vanguard companies create innovation, profits, growth, and social good. London, UK: Profile Books.

Nandakumar, M. K., Jharkharia, S., \& Nair, A. S. (2014). Organisational flexibility and competitiveness. New Delhi, India: Springer Science \& Business Media. https://doi.org/10.1007/978-81-322-1668-1

Nelson, R., \& Winter, S. (1974). Neoclassical vs. Evolutionary theories of economic growth: Critique and prospectus. The Economic Journal, 84(336), 886-905. 
Nelson, R., \& Winter, S. (1982). An evolutionary theory of economic change. Cambridge, MA; London, UK: The Belknap Press of Harvard University Press.

Nelson, R., Dosi, G., Helfat, C., Winter, S., Pyka, A., Saviotti, P., ... Dopfer, K. (2018). Modern evolutionary economics: An overview. Cambridge, UK: Cambridge University Press. https://doi.org/10.1017/9781108661928

Nieto, M. J., Santamaria, L., \& Fernandez, Z. (2015). Understanding the innovation behavior of family firms. Journal of Small Business Management, 53(2), 382-399. https://doi.org/10.1111/jsbm.12075

Nnadozie, E., \& Jerome, A. (2019). Definition and measurement of growth and development. In E. Nnadozie \& A. Jerome (Eds.), African Economic Development (pp. 39-56). Bingley, UK: Emerald Publishing Limited. https://doi.org/10.1108/978-1-78743-783-820192003

Nooteboom, B. (2008). In what sense do firms evolve? (No. 2008-12; Papers on Economics and Evolution). Philipps University Marburg, Department of Geography.

Ohmae, K. (1999). The borderless world: Power and strategy in the interlinked economy. New York: HarperBusiness.

Panagiotakopoulos, A. (2015). Creating a high-skills society during recession: Issues for policy makers. International Journal of Training and Development, 19(4), 253-269. https://doi.org/10.1111/ijtd.12061

Peneder, M. (2017). Competitiveness and industrial policy: From rationalities of failure towards the ability to evolve. Cambridge Journal of Economics, 41(3), 829-858. https://doi.org/10.1093/cje/bew025

Perez, C. (2002). Technological revolutions and financial capital: The dynamics of bubbles and golden ages. Cheltenham, UK: Edward Elgar. https://doi.org/10.4337/9781781005323

Perez, C. (2010). Technological revolutions and techno-economic paradigms. Cambridge Journal of Economics, 34(1), 185-202. https://doi.org/10.1093/cje/bep051

Pitelis, C. N. (2012). On PIIGs, GAFFs, and BRICs: An insider-outsider's perspective on structural and institutional foundations of the Greek crisis. Contributions to Political Economy, 31(1), 77-89. https://doi.org/10.1093/cpe/bzs002

Porter, M. (1998). Location, clusters, and the "new" microeconomics of competition. Business Economics, 33(1), 7-13.

Pyka, A., \& Nelson, R. (2018). Schumpeterian competition and industrial dynamics. In R. Nelson (Ed.), Modern evolutionary economics: An overview (pp. 1-34). Cambridge, UK: Cambridge University Press.

Rahmeyer, F. (2010). A neo-Darwinian foundation of evolutionary economics. With an application to the theory of the firm (No. 309; Discussion Paper Series). Universitaet Augsburg, Institute for Economics.

Rahmeyer, F. (2016). Schumpeter, Marshall, and Neo-Schumpeterian evolutionary economics. Jahrbücher Für Nationalökonomie Und Statistik, 233(1), 39-64. https://doi.org/10.1515/jbnst-2013-0105

Roudometof, V. (2014). Nationalism, globalization and glocalization. Thesis Eleven, 122(1), 18-33. https://doi.org/10.1177/0725513614535700

Sainis, G., Haritos, G., Kriemadis, A., \& Fowler, M. (2016). The willingness of ISO certified Greek SMEs to continue their quality journey to TQM under crisis conditions: A systemic approach. International Journal of Applied Systemic Studies, 6(4), 327-348. https://doi.org/10.1504/IJASS.2016.082168

Scherer, A. G., Palazzo, G., \& Seidl, D. (2013). Managing legitimacy in complex and heterogeneous environments: Sustainable development in a globalized world. Journal of Management Studies, 50(2), 259-284. https://doi.org/10.1111/joms.12014

Schubert, K., \& Zagamé, P. (Eds.). (1998). L'environnement: Une nouvelle dimension de l'analyse économique. Paris: Vuibert.

Schumpeter, J. (1934). The theory of economic development: An inquiry into profits, capital, credit, interest, and the business cycle (R. Opie, Trans.; Reprint Edition: New Brunswick, N.J, Transaction Books, 1983, Social science classics series). Cambridge, MA: Harvard University Press.

Schumpeter, J. (1939). Business cycles: A theoretical, historical and statistical analysis of the capitalist process. New York; London: McGraw-Hill.

Schumpeter, J. (1942). Capitalism, socialism and democracy (Edition published in the Taylor\&Francis e-Library, 
2003). New York; London: Harper \& Brothers.

Siakas, K., Naaranoja, M., Vlachakis, S., \& Siakas, E. (2014). Family businesses in the new economy: How to survive and develop in times of financial crisis. Procedia Economics and Finance, 9, 331-341. https://doi.org/10.1016/S2212-5671(14)00034-3

Sirghi, N. (2014). Evolutionary theory and the market competition. Annals of Faculty of Economics, 1(2), 218-224. https://doi.org/10.5171/2013.697094

Skalkos, D. P. (2018). Studying the political economy of reforms: The Greek case, 2010-2017. Theoretical and Applied Economics, XXV(2(615), Summer, 163-186.

Snyder, H. (2019). Literature review as a research methodology: An overview and guidelines. Journal of Business Research, 104, 333-339. https://doi.org/10.1016/j.jbusres.2019.07.039

Stoelhorst, J. W. (2010). The firm as a Darwin machine: How generalized Darwinism can further the development of an evolutionary theory of economic growth (No. 2010-19; Papers on Economics and Evolution). Philipps University Marburg, Department of Geography.

Triantopoulos, C., \& Staikouras, C. (2017). SOEs in Greece: Structural reforms, economic crisis and financial constraints. International Journal of Public Policy, 13(6), 358. https://doi.org/10.1504/IJPP.2017.087884

United Nations. (2020). Global Humanitarian Response Plan: COVID-19 (United Nations Coordinated Appeal: April - December 2020).

Vasileiou, M., Tsartas, P., \& Stogiannidou, M. (2016). Wellness tourism: Integrating special interest tourism within the Greek tourism market. Tourismos, 11(3), 210-226.

Vassiliadis, S., \& Vassiliadis, A. (2014). The Greek family businesses and the succession problem. Procedia Economics and Finance, 9, 242-247. https://doi.org/10.1016/S2212-5671(14)00025-2

Vecchiato, R. (2015). Strategic planning and organizational flexibility in turbulent environments. Foresight, 17(3), 257-273. https://doi.org/10.1108/FS-05-2014-0032

Vlados, Ch, \& Chatzinikolaou, D. (2019a). Business ecosystems policy in Stra.Tech.Man terms: The case of the Eastern Macedonia and Thrace region. Journal of Entrepreneurship, Management and Innovation, 15(3), 163-197. https://doi.org/10.7341/20191536

Vlados, Ch, \& Chatzinikolaou, D. (2019b). Strategy perception and implementation on less developed business ecosystems micro and small enterprises: The service sector of Eastern Macedonia and Thrace. Business Management and Strategy, 10(2), 27-63. https://doi.org/10.5296/bms.v10i2.15008

Vlados, Ch, \& Chatzinikolaou, D. (2019c). Methodological redirections for an evolutionary approach of the external business environment. Journal of Management and Sustainability, 9(2), 25-46. https://doi.org/10.5539/jms.v9n2p25

Vlados, Ch, Deniozos, N., Chatzinikolaou, D., \& Demertzis, M. (2018a). Towards an evolutionary understanding of the current global socio-economic crisis and restructuring: From a conjunctural to a structural and evolutionary perspective. Research in World Economy, 9(1), 15-33. https://doi.org/10.5430/rwe.v9n1p15

Vlados, Ch, Deniozos, N., Chatzinikolaou, D., \& Demertzis, M. (2018b). Conceptual misunderstandings in the structuration of anti-crisis economic policy: Lessons from the Greek case. Journal of Governance and Public Policy, 5(3), 283-322. https://doi.org/10.18196/jgpp.53100

Vlados, Ch. (2004). La dynamique du triangle stratégie, technologie et management: L'insertion des entreprises grecques dans la globalisation [Thèse de doctorat de Sciences Économiques, Université de Paris X-Nanterre]. Retrieved November 25th, 2020, from http://www.theses.fr/2004PA100022

Vlados, Ch. (2012). The search of competitiveness and the entrepreneurial evolution in a global environment: Toward a new approach of development dynamics based on the case of Greek productive system. Journal of Management Sciences and Regional Development, 8, 91-116. https://doi.org/10.2139/ssrn.3218008

Vlados, Ch. (2019a). On a correlative and evolutionary SWOT analysis. Journal of Strategy and Management, 12(3), 347-363. https://doi.org/10.1108/JSMA-02-2019-0026

Vlados, Ch. (2019b). Change management and innovation in the "living organization": The Stra.Tech.Man approach. Management Dynamics in the Knowledge Economy, 7(2), 229-256. https://doi.org/10.25019/MDKE/7.2.06 
Vlados, Ch. (2019c). The Classical and Neoclassical theoretical traditions and the evolutionary study of the dynamics of globalization. Journal of Economics and Political Economy, 6(3), 257-280. https://doi.org/10.1453/jepe.v6i3.1941

Vlados, Ch. (2019d). Porter's diamond approaches and the competitiveness web. International Journal of Business Administration, 10(5), 33-52. https://doi.org/10.5430/ijba.v10n5p33

Vlados, Ch., \& Chatzinikolaou, D. (2020). Thoughts on competitiveness and integrated industrial policy: A field of mutual convergences. Research in World Economy, 11(3), 12. https://doi.org/10.5430/rwe.v11n3p12

Williams, C. C., \& Nadin, S. (2011). Theorising the hidden enterprise culture: The nature of entrepreneurship in the shadow economy. International Journal of Entrepreneurship and Small Business, 14(3), 334-348. https://doi.org/10.1504/IJESB.2011.042757

Williams, N., \& Vorley, T. (2015). The impact of institutional change on entrepreneurship in a crisis-hit economy: The case of Greece. Entrepreneurship \& Regional Development, 27(1-2), 28-49. https://doi.org/10.1080/08985626.2014.995723

Winter, S. G. (2006). Toward a neo-Schumpeterian theory of the firm. Industrial and Corporate Change, 15(1), 125-141. https://doi.org/10.1093/icc/dtj006

Xie, Y. H., \& Suh, T. (2014). Perceived resource deficiency and internationalization of small- and medium-sized firms. Journal of International Entrepreneurship, 12(3), 207-229. https://doi.org/10.1007/s10843-014-0121-9

Zaccaï, E. (2002). Le développement durable: Dynamique et constitution d'un projet. Bruxelles; New York: P.I.E.-Peter Lang.

\section{Copyrights}

Copyright for this article is retained by the author(s), with first publication rights granted to the journal.

This is an open-access article distributed under the terms and conditions of the Creative Commons Attribution license (http://creativecommons.org/licenses/by/4.0/). 